\title{
Editorial
}

Revista Digital do LAV - Laboratório de Artes Visuais - vol.9, n.1, jan./abr. 2016.

ISSN: $1983-7348$

In memoriam de Ricardo Reis Arte educador/pesquisador

Prezados leitores e leitoras (1979-2015)

É com satisfação que apresentamos mais um número da Revista Digital do Laboratório de Artes Visuais.

Pela primeira vez homenageamos um colega da nossa área acadêmica. Dedicamos este número ao jovem arte educador português Ricardo Reis falecido há cerca de um ano atrás vitima de doença incurável. Deixou muitos amigos no Brasil. À sua família, devemos uma palavra de agradecimento pela gentileza de ceder-nos os direitos de publicação do seu artigo. Os amigos cederam-nos o texto, garimpado entre as publicações dispersas desse mundo editorial que tanto em Portugal, como no Brasil, poderemos chamar "menor". Referimo-nos às pequenas revistas cujos editores partilham conosco essa militância voluntariosa pela educação, pela arte e cultura.

$\mathrm{O}$ artigo de Ricardo Reis $\boldsymbol{O}$ que nos dizem as imagens que vêm os nossos alunos: Uma reflexão sobre as imagens que os professores de arte mostram aos seus alunos, póstumo, é uma adaptação autorizada de um artigo original do autor publicado em Portugal em 2011 na Revista Argumento, Ano XXVIII, n¹39, Set./Out. págs.13-15. Tem como objetivo principal o estudo de práticas prevalecentes entre os professores de arte em Portugal a partir de uma conceitualização à volta da literacia visual e da cultura visual. Tanto quanto possível foi respeitada a versão inicial do autor.

Ricardo Jorge Reis Silva teve uma promissora mas curta carreira acadêmica. Nasceu na pequena cidade histórica de Óbidos em 2 de maio de 1979 e faleceu aos 35 anos, em 20 de março de 2015, vítima de uma doença incurável e fulminante: a esclerose lateral amiotrófica. Um ano depois da sua morte, a Revista Digital do LAV presta, portanto, uma homenagem a um dos produtivos

Revista Digital do LAV - Santa Maria - vol. 9, n. 1, p. 1 - 4. - jan./abr. 2016 ISSN 1983 - 7348 http://dx.doi.org/10.5902/1983734822088 
pesquisadores na área da visualidade em Portugal. Doutorando na Universidade de Barcelona, Espanha, continuou com a elaboração da sua tese mesmo depois de manifestada essa doença fatal que não conseguiu vencer. Deixa-nos um grande exemplo de dedicação, tenacidade e persistência, sem dúvida, qualidades fundamentais para quem quer fazer pesquisa na universidade contemporânea.

Da Unicamp, chega-nos a proposta de Silvio Gallo Algumas notas em torno da pergunta: "o que pode a imagem?". Jogando com a proposição do filósofo seiscentista Espinoza ( $O$ que pode um corpo?) o autor, a partir do pensamento deleuzeano, procura ultrapassar a ideia de uma concepção da imagem como mera ilustração e como mera comunicação, refletindo, com a ajuda das imagens do cinema, sobre outras potências da imagem, como a imagem-sensação e a imagem pensamento.

Anna Leticia Pereira de Carvalho da Faculdade Metrocamp é a autora do artigo $\boldsymbol{A}$ ficção em Joan Fontcuberta: uma análise da obra Sputnik no qual disserta sobre teoria da fotografia e artes visuais contemporâneas, tomando como referência um importante projeto de um dos mais originais e criativos artistas espanhóis vivos, onde, entre outras conceitualizações, é explorada a dicotomia verdade/mentira das imagens fotográficas de pressuposto cariz histórico.

\section{Em Quais experiências transformam uma pessoa em um professor de}

Artes Visuais? Henrique Lima Assis, pesquisador da Unicamp, apresenta-nos um recorte da sua pesquisa doutoral que consistiu em estudar as narrativas que podem desenvolver-se a partir dos objetos que costumamos guardar em nossas casas e como eles acabam por influenciar intimamente nossas vidas profissionais.

Novamente o pensamento de filósofo Gilles Deleuze voltou a servir de referência teórica, em particular, o seu plano de imanência. Esta constituiu a dimensão conceitual do artigo Deslocamentos deleuzianos na pesquisa em artes visuais: estratégias para uma prática híbrida através da imagem, proposto Maria Romagnoli Bethonico, pesquisadora na Université Sorbonne la Nouvelle (Paris III) e Roberta Carvalho, da Pontifícia Universidade Católica de Minas Gerais. Neste artigo é mapeado o papel da imagem no âmbito da produção

Revista Digital do LAV - Santa Maria - vol. 9, n. 1, p. 1 - 4. - jan./abr. 2016 ISSN 1983 - 7348 http://dx.doi.org/10.5902/1983734822088 
artística atual e como ambos podem contribuir para a construção de métodos de pesquisa singulares.

Ana Lúcia Louro, Ziliane Lima de Oliveira Teixeira e André Muller Reck, da Universidade Federal de Santa Maria, em a Pesquisa em Música: Reflexões sobre memórias musicais e dimensões da "experiência de si" abordam as narrativas orais e escritas dos alunos de licenciatura, tomando como referencial teórico as dimensões implicadas na "Experiência de si" propostas por Jorge Larrosa.

Também da Universidade Federal de Santa Maria, Jair dos Santos Gonçalves e Andreia Machado de Oliveira propõem o artigo Música visual interativa: propostas interdisciplinares para as tecnologias educacionais em rede. Esta pesquisa cruza, de forma interativa, a arte contemporânea, suas dimensões performativas, e as tecnologias educacionais em rede. Aborda o conceito de musica visual e procura conceber outras possibilidades interdisciplinares para a área da educação musical.

Elson de Assis Rabelo e Rafaela Novaes Feitoza apresentam-nos Um lugar para a fotografia: uma breve análise da constituição e produção do Coletivo FotoBahia (1979-1980). Este texto analisa o surgimento e a produção do Coletivo FotoBahia, em Salvador, no final dos anos 1970, com o objetivo de colocar em discussão os propósitos de suas atividades, a elaboração da linguagem fotográfica e sua inserção na produção cultural baiana.

Paulino Antonio da Silva Moreira da Universidade Federal de Goiás nos brinda o texto Vídeo como potencializador da arte educação digital crítica onde discute a utilização do vídeo como potencializador da e-arte/educação. O material é fruto do trabalho de conclusão do curso de Especialização em Arte/Educação Intermidiática Digital. Problematiza-se os atos corriqueiros de violência e que devido a tanta incidência dos mesmos, tornam-se comuns.

Kelly Sabino da Universidade de São Paulo apresenta-nos a pesquisa Albers e Kaprow: notas sobre o saber da arte na educação onde reflete sobre o ensino da arte a partir de uma dupla investigação: verificar o "saber da arte" 
presente na arte-educação e averiguar formas de entender a aula de arte como criação a partir dos procedimentos artísticos apresentados pelo "saber da arte." Como contributo traz escritos dos artistas Allan Kaprow e Joseph Albers sobre as suas práticas artístico-docentes como possíveis lastros investigativos para uma prática docente baseada na criação artística.

Este número inicial do volume nono da Revista Digital do Laboratório de Artes Visuais, corporiza, novamente, um duplo esforço: por um lado, o de transdisciplinarização assumida, envolvendo um amplo espectro de áreas artísticas, nem todas necessariamente visuais, por outro lado, continua apostando em uma internacionalização que tem vindo a ser respondida a partir de vários quadrantes geográficos. Essa abrangência global pelo espaço latinoamericano, apesar desta vez não contemplar a língua espanhola, é exemplificada pela proveniência de textos de investigadores que pesquisam ou pesquisaram em pelo menos três países, reforçando uma política e uma filosofia de publicação assumida pelos seus editores, desde há algum tempo, e julgada fundamental não só para a qualificação da revista, como também para a própria missão da mesma. Oportunizar aos nossos leitores o conhecimento dessas propostas de fora e a experimentação desses olhares estrangeiros será, acreditamos, uma forma de ativismo científico-cultural que qualquer revista universitária de acesso livre deveria ter. Isto será tanto mais importante quanto a tendência para a internacionalização dos vários dispositivos e modos de funcionamento universitários, nestes tempos de grande instabilidade e incerteza.

Os Editores

Marilda Oliveira de Oliveira Leonardo Charréu 